\title{
ACUTE TOXICITY OF JATROPHA CURCAS OIL ON PLANT CELL CYCLE
}

\author{
TOXICIDADE AGUDA DO ÓLEO DE JATROPHA CURCAS NO CICLO CELULAR \\ DE PLANTAS
}

\author{
Larissa Fonseca ANDRADE-VIEIRA ${ }^{1}$; Carolina Mastella BOTELHO²; \\ Bruno Galvêas LAVIOLA ${ }^{3}$; Adésio FERREIRA ${ }^{4}$; Milene Miranda PRAÇA-FONTES ${ }^{4}$ \\ 1. Adjunct Professor, Federal University of Lavras, Lavras, MG, Brazil; 2. Student of Pharmacy, Federal University of Espírito Santo, \\ Alegre, ES, Brazil; 3. Brazilian Agricultural Research Corporation, Brasília, DF, Brazil; 4. Associate Professor, Federal University of \\ Espírito Santo, Alegre, ES, Brazil. milenemiranda@yahoo.com.br
}

\begin{abstract}
Today, a great interest in Jatropha-based products exists worldwide, mainly for the production of biofuel. However, the oil obtained from this plant is known to be toxic due to contained curcins and phorbol esters. Bioassays, including plant cytogenetic assays based on cell cycle observation, are useful for determining the toxicity of $J$. curcas oil. Hence, the aim of this study was to describe the mechanism of action of $J$. curcas oil by cell cycle analysis using Lactuca sativa as plant testing model. A decrease in root growth was observed, closely related to the reduction in mitotic index, along with an increase in condensed nuclei. $J$. curcas chemicals act both as aneugenic agents, leading to the formation of lagged, sticky chromosomes and cmetaphase cells, as well as clastogenic agents, inducing the formation of chromosome bridges and fragments. The cytotoxicity and genotoxicity of phorbol esters and other chemical components of $J$. curcas oil was determined and discussed.
\end{abstract}

KEYWORDS: Aneugenic effects. Lactuca sativa. Mitotic index. Phorbol esters. Root growth.

\section{INTRODUCTION}

Jatropha curcas L. (Euphorbiaceae) is a promising plant for biofuel production ( $\mathrm{Li}$ et al. 2010, Devappa et al. 2012). Its seeds contain about $35-45 \%$ of oil that could be converted into highquality biodiesel upon transesterification (RAKSHIT et al. 2008, LI et al. 2010). However, the oil obtained from this plant is known to be toxic, due to the presence of two chemical compounds: curcin and phorbol esters (PEs). The assessment of toxicity of $J$. curcas oil has been determined by in vitro tests using lower organisms as models, including snails, brine shrimp, and daphnia, and also animals such as mice and rats (MAKKAR; BECKER 1999, RAKSHIT et al. 2008, Li et al. 2010, Devappa et al. 2012, Silva et al. 2012).

In these studies, toxic effects of the natural compounds present in J. curcas could be attributed mainly to phorbol esters (PEs), toxic phytochemicals commonly found in plants of the Euphorbiaceae family, primarily in the genus Jatropha. The concentrations of these compounds may vary according to the genetic characteristics of the plant; J. curcas oil has been reported to contain $70-75 \%$ of PEs, a diterpene soluble in lipids and extracted together with the oil (DEVAPPA et al. 2012).

Bioassays, including plant cytogenetic assays based on cell cycle observation, are useful in determining the toxicity of $J$. curcas oil, as they are fast, sensitive, reliable, and also present high functionality in other test systems, such as animals (ANDRADE-VIEIRA 2012). The cell cycle parameters normally assessed are (i) mitotic index (MI), calculated as the fraction of dividing cells in the total of observed cells; (ii) percentage of chromosome aberrations (CAs), expressed in number of aberrations - c-metaphases, stickiness, bridges and laggards - divided by the total number of cells; and (iii) nuclear aberrations (NAs), determined by the frequency of condensed nuclei, lobated nuclei, and poly- and micronucleated cells in interphase (ANDRADE et al. 2008, LEME et al. 2008). These parameters define the genotoxicity, cytotoxicity and mutagenicity of the compound tested, whereas the different chromosomal aberrations could evidence the mechanism of action of the compound on the genetic material, leading to clastogenic (chromosome breakage) or aneugenic (chromosome lagging and alterations on the spindle) effects (LEME; MARIN-MORALES 2009).

The available cytogenetic protocols using plant species as bioindicators are efficient to biomonitor the extent of toxicity and mutagenicity of complex compounds such as J. curcas oil, providing insights into the risks to human health and other target organisms. Lactuca sativa is one of the test systems available to detect the effects of chemical compounds on the cell cycle of model 
organisms (Andrade et al. 2010). It is considered a very useful plant for cytogenetic analysis, as it presents high number of seeds, high degree of contact with the solution in study, high sensitivity, small number of chromosomes $(2 \mathrm{n}=2 \mathrm{x}=18)$ (Campos et al. 2008) with large size. Hence, the aim of this study was to describe the mechanism of action of $J$. curcas oil by cell cycle analysis using $L$. sativa as plant testing model.

\section{MATERIAL AND METHODS}

\section{Materials}

Jatropha curcas oil was extracted according to Makkar et al. (1997) with modifications. The ground seeds were placed in a standard Accelerated Solvent Extractor - ASE 350 (Dionex, USA) using the solvent tetrahydrofuran, which was evaporated under a flow of nitrogen. The oily residue was transferred to a $10 \mathrm{~mL}$ test tube, extracted four times with methanol $(2 \mathrm{~mL}+1 \times 3 \times 1 \mathrm{~mL})$, transferred to a $5 \mathrm{~mL}$ volumetric flask, and the total volume was filled up to $10 \mathrm{~mL}$ with methanol.

Seeds of Lactuca sativa $\mathrm{L}$. $(2 \mathrm{n}=2 \mathrm{x}=18)$ of the commercial cultivar "Grandes Lagos Americano" (Isla Sementes) were used as test system material. The seeds were placed on germination paper previously moistened with $5 \mathrm{~mL}$ of distilled water to stimulate root emergence. Next, they were placed in Petri dishes covered with aluminum foil to protect the seeds from any light, and the dishes were incubated in a germination chamber maintained at $24 \pm 2^{\circ} \mathrm{C}$. The germinated seeds were treated with the test solutions when reaching a root length of $0.5 \mathrm{~cm}$.

\section{Treatment solutions}

$J$. curcas crude oil was mixed with water by intense agitation and quickly applied onto germination paper in a Petri dish $(120 \mathrm{~mm})$. Three oil concentrations, previously determined based on $\mathrm{IC}_{50}$ concentration (inhibition concentration 50\% the concentration at which $50 \%$ of root growth inhibition occurs), were tested for their toxicity: $\mathrm{JC}_{1}$ $=22.5 \%, \mathrm{JC}_{2}=45 \%$ and $\mathrm{JC}_{3}=67.5 \%$ of oil, corresponding to half, one, and one and a half times $\mathrm{IC}_{50}$, respectively. Distilled water was used as negative control solution.

\section{Root Growth Analysis}

Thirty pre-germinated seeds were placed into each Petri dish, then subjected to treatments at $24 \pm 2^{\circ} \mathrm{C}$ in a germination chamber. The treatments were arranged in a completely random design with three replicates for each treatment solution, each replication including three Petri dishes. The root lengths were measured with a digital caliper after exposure to distilled water and after $48 \mathrm{~h}$ of exposure to J. curcas oil treatments. There were 270 root growth (RG) measurements for each concentration. The final root growth for each treatment was obtained by calculating the difference between root length after exposure to $J$. curcas oil and root length after exposure to distilled water.

\section{Cytogenetic Analysis}

At least five roots per Petri dish per treatment were collected after the root length measurements ( $48 \mathrm{~h}$ after exposure). The roots were fixed in fresh, cold solution of ethanol and acetic acid $(3: 1 \mathrm{v} / \mathrm{v})$. Fixed root tips were hydrolyzed in $1 \mathrm{~N} \mathrm{HCl}$ at $60^{\circ} \mathrm{C}$ for $10 \mathrm{~min}$, and squashed with acetic orcein $(2 \%)$. Nine roots per treatment (each root from a different Petri dish) were used to prepare the slides. The slides were analyzed under a light microscope, and about 10,000 cells were scored per treatment. The following parameters were analyzed: (i) mitotic index (MI), calculated as the number of dividing cells as a fraction of the total number of cells; (ii) chromosomal alterations (CA), expressed as the percentage of number of aberrations - c-metaphase cells, sticky chromosomes, bridges, laggards and fragments divided by the total number of cells; and condensed nuclei $(\mathrm{CN})$, determined by the frequency of strongly stained nuclei in interphase.

\section{Statistical Analysis}

Data were subjected to one-way analysis of variance (ANOVA), and the averages of all analyzed parameters (RG, MI, and nuclear/chromosomal/mitotic alterations) were compared by Dunnet's test at 5\% probability level. Statistical analysis was performed using the statistical program " $R$ " (R Development Core Team 2009).

\section{RESULTS AND DISCUSSION}

We found that all applied treatments significantly reduced the elongation of roots compared to control (Table 1). The greatest observed reduction was $36 \%$ (JC3). Further, $J$. curcas oil significantly inhibited the MI (Table 2). Analysis results on the effects of J. curcas oil on MI showed significant differences for all tested concentrations in relation to the control. Maximum reduction in MI was observed after JC3 treatment, being approximately $45 \%$ lower than the control. The incubation of root tip cells in J. curcas oil also 
changed the frequency of each mitotic phase in accordance with the oil concentration (Table 2). The number of dividing cells in metaphase increased
$67 \%$, while the percentage of prophase, anaphase and telophase cells decreased dramatically, with a reduction of $75 \%$ for telophases.

Table 1. Root growth (RG), in millimeter, after J. curcas treatments

\begin{tabular}{llll}
\hline Treatment & RG before treatment & RG post treatment & Average of growth in 24h \\
\hline Control & $3.91 \pm 0.43^{\mathrm{a}}$ & $12.44 \pm 0.54$ & 8.53 \\
JC 1 & $3.76 \pm 0.51$ & $9.53 \pm 0.22^{*}$ & $5.77^{*}$ \\
JC 2 & $3.89 \pm 0.39$ & $9.32 \pm 0.31^{*}$ & $5.43^{*}$ \\
JC 3 & $3.87 \pm 0.27$ & $9.28 \pm 0.46^{*}$ & $5.43^{*}$ \\
\hline
\end{tabular}

${ }^{a}$ Mean values with standard deviation. Values marked with * differ significantly from the control accordingly Dunnet's test (p<0.05).

Table 2. Mitotic index (MI) and frequency of each mitotic phase in L. sativa cells after exposure to J. curcas oil

\begin{tabular}{|c|c|c|c|c|c|c|c|c|}
\hline \multirow[b]{2}{*}{ Treatments } & \multirow{2}{*}{$\begin{array}{l}\text { Total } \\
\text { cells }\end{array}$} & \multirow{2}{*}{$\begin{array}{l}\text { Total } \\
\text { cells }\end{array}$} & \multirow{2}{*}{ dividing } & \multirow[b]{2}{*}{ MI } & \multicolumn{4}{|c|}{ Mitotic phase (\%) } \\
\hline & & & & & $\mathbf{P}$ & $\mathbf{M}$ & $\mathbf{A}$ & $\mathbf{T}$ \\
\hline $\mathrm{C}$ & 14535 & 1274 & & $8.76 \pm 0.36^{\mathrm{a}}$ & 56.98 & 24.49 & 16.01 & 2.51 \\
\hline $\mathrm{JC} 1$ & 13227 & 674 & & $5.09 \pm 1.41 *$ & 56.37 & 27.30 & 14.98 & 1.34 \\
\hline $\mathrm{JC} 2$ & 11473 & 597 & & $5.20 \pm 0.89 *$ & 56.11 & 39.53 & 13.06 & 1.34 \\
\hline $\mathrm{JC} 3$ & 13215 & 655 & & $4.95 \pm 1.07 *$ & 47.33 & 40.61 & 10.99 & 0.61 \\
\hline
\end{tabular}

${ }^{\mathrm{a} M I}$ values followed by standard deviation. Values marked with * differ significantly from; control according to Dunnet's test ( $\left.\mathrm{p}<0.05\right)$. $\mathrm{P}=$ prophase $\mathrm{M}=$ metaphase; $\mathrm{A}=$ anaphase $\mathrm{T}=$ telophase.

The present study reported the effects of $J$. curcas oil on the cell cycle of $L$. sativa. The phyto-, cyto-, and genotoxic effects of $J$. curcas oil were demonstrated here for the first time, suggesting the use of a plant bioassay as a reliable test to determine the toxicity of $J$. curcas oil. In addition, we also reported and discussed the mode of action of $J$. curcas oil on the cell cycle.

Cytogenetic bioassays using plants as test models are reliable tools for assessing the effects of chemicals and toxic agents on living organisms (ANDRADE-VIEIRA 2012). The mitotic index is a reliable measure for determining the presence of cytotoxic compounds in the environment, and is a suitable test for biomonitoring pollution levels (SMAKA-KINCL et al. 1996, FERNANDES et al. 2007). Inhibition of MI can be attributed to effects of chemicals on DNA and protein synthesis in a biological system (Chauhan et al. 1998). The mechanisms of action of these chemicals can be accessed by the occurrence of CAs and $\mathrm{CN}$, as well as the type of these alterations.

The differences in CA values for mitotic cells of control and exposed root tips are presented in Table 3. All treatments significantly increased CA in mitotic cells. The highest average $(1.76 \%)$ of CA was found in JC2 treatment, representing six times the frequency of CA recorded in control cells
$(0.21 \%)$. A wide range of CAs, such as chromosomal bridges, c-metaphases, fragments, lost and sticky chromosomes, was detected after $J$. curcas oil exposure (Table 3). Spindle disturbances were the most prominent effects of $J$. curcas oil on $L$. sativa cells, as revealed by the frequency of cmetaphases, sticky and lost chromosomes (Figure 1 ), representing $71-82 \%$ of the total alterations counted in treated cells. Other alterations (bridges and fragments) were recorded at low frequencies $(17-28 \%)$ in treated roots.

With regard to $\mathrm{CN}$, statistical data showed that only the highest J. curcas oil concentration (JC3) differed significantly from the control (Table 3 ). The 2.85-fold higher frequency compared to control cells reflects the presence of condensed nuclei, characterized by an alteration in their normal structure, leading to a strongly stained appearance at microscopy. 
Table 3. Chromosome alterations (CA) and nuclear alterations (NA) induced by J. curcas oil in L. sativa cells

\begin{tabular}{llllllllll}
\hline Treat & CA & Lost & C-met & Sticky & Bridges & Frag & Aneug & Clast & CN \\
\hline C & $0.21 \pm 0.05^{\mathrm{a}}$ & 0.02 & 0.03 & 0.15 & 0.0 & 0.01 & 0.2 & 0.01 & $3.39 \pm 1.13^{\mathrm{a}}$ \\
$\mathrm{JC} 1$ & $1.23 \pm 0.22^{*}$ & 0.14 & 0.28 & 0.46 & 0.09 & 0.26 & 0.88 & 0.35 & $7.04 \pm 2.92$ \\
JC2 & $1.76 \pm 0.31^{*}$ & 0.18 & 0.21 & 1.07 & 0.08 & 0.22 & 1.407 & 0.3 & $7.46 \pm 2.78$ \\
JC3 & $1.28 \pm 0.69^{*}$ & 0.06 & 0.13 & 0.80 & 0.08 & 0.21 & 0.99 & 0.29 & $9.68 \pm 0.96^{*}$ \\
\hline
\end{tabular}

Means values represents the frequency in relation to total cells observed. ${ }^{\mathrm{a}} \mathrm{CA}$ and $\mathrm{CN}$ values followed by standard deviation. Values marked with $*$ differ significantly from the control accordingly Dunnet's test $(\mathrm{p}<0.05)$. C-Met $=\mathrm{c}$-metaphase; Frag $=$ fragments; Aneug $=$ aneugenic , Clast $=$ clastogenic .
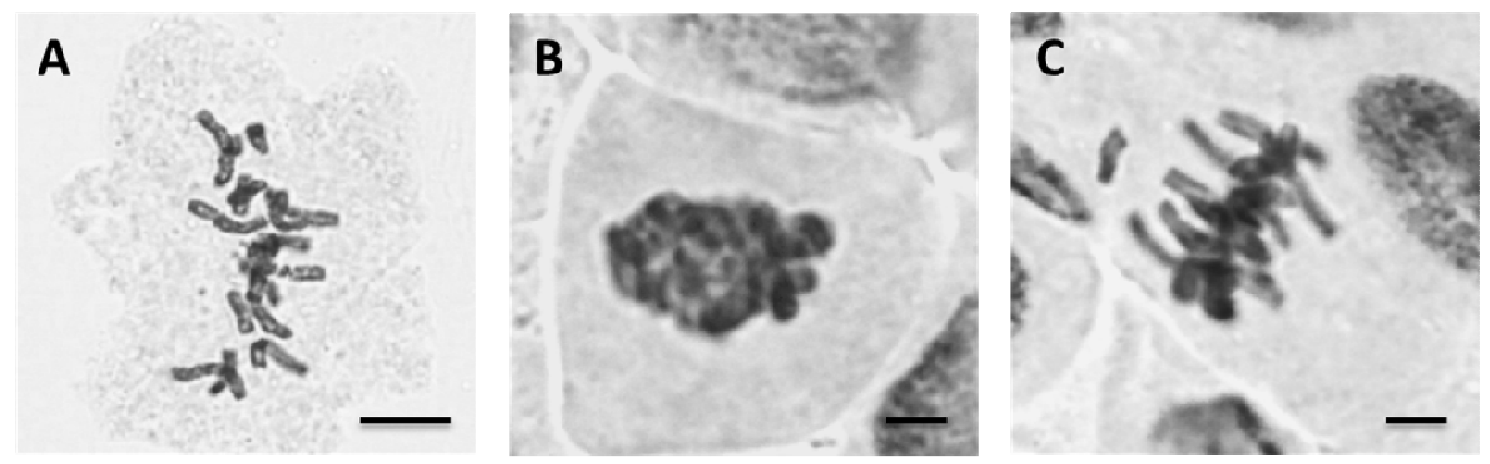

Figure 1. Meanly mitotic alterations induced by J. curcas oil in meristematic cells of L. sativa. (A) Cmetaphase. (B) Sticky chromosomes. (C) Metaphase with lost chromosome. Bars $=5 \mu \mathrm{m}$.

The analysis of root tips cells exposed to $J$. curcas oil, including the macroscopic parameter RG and the microscopic ones MI, CA and $\mathrm{CN}$, determines and defines the mechanism of action of chemicals in $J$. curcas oil. These are integrated parameters that evidence both the cyto- and the genotoxicity of these chemicals, as discussed here. A decrease was observed in RG, closely related to a reduction in $\mathrm{MI}$ and an increase in $\mathrm{CN}$, which explains the mode of action of chemicals in $J$. curcas oil. In plant cells, the growth of an organ such as the root is intimately dependent on the increase in the number of cells, which occurs through various mitotic cycles, and also on the cell elongation during the development and differentiation process (HARASHIMA; SCHNITTGER 2010). This way, the MI is naturally directly correlated with $\mathrm{RG}$, as cell proliferation after a mitotic cycle increases the number of cells, contributing to the growth of the organ. Apart from lowering the MI, J. curcas oil also drastically increases the percentage of $\mathrm{CN}$ (Tables 2 and 3). These two parameters reflect the reduction in root elongation after treatments. Andrade-Vieira et al. (2011) discussed that the presence of $\mathrm{CN}$ is associated with the programmed cell death (PCD) displayed at abiotic stress conditions. In the present article, the chemicals present on J. curcas oil, including PEs, constitute abiotic stress agents that lead to cell death.
PEs are diterpene analogs of diacylglycerol, an activator of many isoforms of protein kinase $\mathrm{C}$ (PKC) (ZHANG et al. 1995, KING et al. 2009). These isoforms of PKC are well known and studied in animal cells, and are associated with the regulation of both positive and negative signal transduction pathways, essential for the initiation and homeostasis of immune responses (SPITALER; CANTRELl 2004). In plants, these PKC isoforms are considered a type of $\mathrm{Ca}^{2+}$-dependent protein kinase (CDPK), as calcium is the main activator of these proteins. In plant mesophyll cells, a CDPK showing several characteristics of the conventional type of mammalian PKC has been detected, but it was not activated by PEs (OSUNA et al. 2004). Further, Liese; Romeis (2013) studied the function of CDPK, and discussed that variants lacking the regulatory $\mathrm{Ca}^{2+}$-binding domain are correlated with the induction of plant defense reactions, including Reactive Oxygen Species (ROS) production, changes in phytohormone levels, defense gene expression, and cell death occurrence. These factors explain why the presence of $\mathrm{CN}$ associated with PCD as well as PEs does not activate PKC-like proteins, and the plant immune defense pathway becomes compromised, leading to cell death.

Apart from this, by analyzing the frequency of each mitotic phase, including the cell cycle abnormalities (Tables 2 and 3), the cytotoxicity and genotoxicity of PEs and other chemical components of J. curcas oil could be determined. The 
cytotoxicity is characterized by the mitodepressive effect of $J$. curcas oil, arresting the cell cycle, and the presence of cells with nuclear alterations such as $\mathrm{CN}$. On the other hand, the genotoxicity of the compounds is defined by the range of chromosome alterations observed during mitotic phases (LEME; MARIN-MORALES 2009). With regard to cytotoxic effects, $J$. curcas oil increased the percentage of metaphase cells, in detriment of anaphase and telophase ones. The progress of cell cycle and mitotic phases depend on the phosphorylation and dephosphorylation of specific cell proteins, which constitute the cell cycle control proteins, including the family of cyclins and kinases. During the cell cycle, a specific phase is initiated when a given cyclin binds to a corresponding kinase; then, the activation of the complex by phosphorylation and dephosphorylation is followed by the progress in cell phases (ALBERTS et al. 2008). The degradation of cyclins is also important to the progress of mitotic phases. During metaphases, the Anaphase Promoter Complex (APC/C) is activated by phosphorylation, leading to the degradation, by ubiquitylation, of securins. Then, proteins that keep the sister chromatids together, the coesins, are dissociated, thus disrupting the sister chromatids and allowing the spindle fiber to pull them to different poles, initiating the anaphase (ALBERTS et al. 2008). Here we observed that $J$. curcas oil components inhibited anaphases, suggesting that chemicals present in the oil affected the phosphorylation and ubiquitylation processes involved in anaphase activation, arresting the cell cycle at metaphase.

In addition, the progress of the cell cycle depends on checkpoints that verify if cells are ready to start the new phase. For instance, the G2 checkpoint prevents damaged cells from starting mitosis, blocking these cells at G2 (Alberts et al. 2008). This way, chromosome damage can delay the cell cycle progress, contributing to the decrease of early mitotic phases, such as prophase, while the frequency of G2 cells increases. Such a mechanism was observed by Andrade-Vieira et al. (2012) as a consequence of abiotic stress due to exposure to industrial waste. As reported in the literature, here we also observed a decrease in prophase cells as well as an increase in the percentage of bridges and fragments, mainly related to breakages and fusion of chromosomes (CAMPOS et al. 2008) due to exposure to J. curcas oil. As these chromosome alterations reflect the possibility of chemicals of $J$. curcas oil affecting DNA strands, these clastogenic alterations could be associated with the decrease in early mitotic phases, as discussed above.
The presence of sticky and c-metaphases also contributes to the increase in metaphase cells observed after $J$. curcas oil treatment. In this case, another mechanism is involved. The c-metaphase cells are a consequence of the action of chemicals on the spindle fibers, preventing the continuation of the mitotic cycle (LEME; MARIN-MORALES 2009). This occurs by two mechanisms: chemicals could (1) link to spindle proteins (tubulins), thus preventing microtubule formation; or (2) link to the spindle, stabilizing microtubules, hence preventing chromatid migration and paralyzing the mitotic process in metaphase (ALBERTS et al. 2008). As a result of this disorganization, the cell cycle is interrupted at metaphase, and the chromosomes are seen scattered and condensed, with very welldefined centromeres (FISKEJÖ 1985). These mechanisms also arrest cell division, contributing to a decrease in MI. Sticky metaphases are observed when chemicals link to chromosome scaffold proteins. The action of chemicals on the physicochemical structure of the DNA and/or proteins leads to complex formations, with phosphate groups in the DNA, condensation of the DNA, or the formation of inter- and intra-chromatid links (EL-GHAMERY et al. 2003). It causes agglomerate formations, as DNA from different chromosomes bind to each other. This way, the chromosomal structure cannot be maintained, leading to a change in the typical appearance of chromosomes, which lose the characteristics of normal chromosomal condensation (BABICH et al. 1997). This is a severe and irreversible chromosome damage that generally leads to cell death, reflecting the genotoxic effects of $J$. curcas oil. Both sticky chromosomes and cmetaphases are abnormalities that characterize the aneugenic action of the components of $J$. curcas oil. The increase in $\mathrm{CN}$, associated with the process of programmed cell death (ANDRADE-VIEIRA et al. 2011), reinforces the genotoxic effects of $J$. curcas oil on L. sativa cells.

In summary, there is great interest in Jatropha-based products worldwide. Yet, due to the possibility of humans/animals coming into contact with the toxic chemicals in Jatropha products, studies that evaluate the toxicity of these compounds, giving answers regarding their mechanisms of action, as we described here, are necessary to subsidize environmentally correct solutions.

\section{CONCLUSION}

The present study contributes to understanding the effects of $J$. curcas chemicals on 
organisms in the environment, demonstrating that testing with Lactuca sativa is a fast and sensitive assay to determine the mode of action of genotoxic and mutagenic compounds in Jatropha curcas seed extracts, integrating macroscopic and microscopic data. Importantly, it can be concluded that J. curcas chemicals act as aneugenic agents, leading to the occurrence of lagging, sticky chromosomes and cmetaphase cells; and as clastogenic ones, inducing the formation of chromosome bridges and fragments.

\section{ACKNOWLEDGEMENTS}

We would like to thank the Fundação de Amparo à Pesquisa do Estado do Espírito Santo (FAPES- UNIVERSAL; Grant 80707114/18), Conselho Nacional de Desenvolvimento Científico e Tecnológico (CNPq) and Coordenação de Aperfeiçoamento de Pessoal de Nível Superior (CAPES) for the financial support.

RESUMO: Um grande interesse mundial existe em produtos à base de pinhão manso, principalmente para a produção de biocombustíveis. No entanto, o óleo obtido a partir desta planta é conhecidamente tóxico por conter curcina e ésteres de forbol. Bioensaios, incluindo ensaios citogenéticos em plantas-modelo com base na observação do ciclo celular, são úteis para determinar a toxicidade do óleo de J. curcas. Assim, o objetivo deste estudo foi descrever o mecanismo de ação do óleo de $J$. curcas por análise do ciclo celular usando Lactuca sativa como modelo de teste em plantas. Foi observada uma redução no crescimento das raízes, intimamente relacionada com a redução do índice mitótico e com um aumento de núcleos condensados. Os constituintes químicos de $J$. curcas atuam simultaneamente como agentes aneugênicos, levando à formação de cromossomos perdidos e pegajosos e células em c-metáfase, bem como agentes clastogênicos, induzindo a formação de pontes e fragmentos cromossômicos. A citotoxicidade e genotoxicidade do éster de forbol e outros componentes químicos do óleo de J. curcas foram determinados e discutidos.

PALAVRAS-CHAVE: Efeitos aneugênicos. Lactuca sativa. Índice mitótico. Éster de forbol. Crescimento radicular.

\section{REFERENCES}

ALBERTS, B. et al. Molecular Biology of the Cell. 5 ed. New York: Garland Publishing, 2008.

ANDRADE, L. F. et al. Cytogenetic alterations induced by SPL (spent potliners) in meristematic cells of plant bioassays. Ecotoxicology and Environmental Safety, v. 71 n. 3, p. 706-710, 2008. https://doi.org/ 10.1016/j.ecoenv.2008.02.018

ANDRADE, L. F. et al. The effect of cyanide compounds, fluorides, aluminum, and inorganic oxides present in spent pot liner on germination and root tip cells of Lactuca sativa. Ecotoxicology and Environmental Safety, v. 73, n. 4, p. 626-631, 2010. https://doi.org/10.1016/j.ecoenv.2009.12.012

ANDRADE-VIEIRA, L. F. Toxicity of Landfills Assessed by Plant Cytogenetic Approaches. In: Landfills: waste management, regional practices, and environmental impact (GBC Cabral and BAE Botelho, eds), New York: Nova Publishers, 2012. p. 319-330.

ANDRADE-VIEIRA, L. F. et al. Spent Pot Liners (SPL) induced DNA damage and nuclear alterations in root tip cells of Allium cepa as a consequence of programmed cell death. Ecotoxicology and Environmental Safety, v. 74, n. 4, p. 882-888, 2011. https://doi.org/ 10.1016/j.ecoenv.2010.12.010

BABICH, H. et al. The Allium test - a simple, eukaryote genotoxicity assay. The American Biology Teacher, v. 59, n. 9, p. 580-583, 1997. https://doi.org/10.2307/4450386

CAMPOS, J. M. S. et al. Genetic Toxicology and Environmental Mutagenesis in Allelopathic Interactions. In: Plant Bioassays. ed. Houston : Studium Press, 2008. 
CHAUHAN, L. K. S. et al. Diuron induced cytological and ultrastrucutural alterations in the root meristem cells of Allium cepa. Pesticide Biochemical and Physiology, v. 62 n. 3, p. 152-163, 1998.

https://doi.org/10.1006/pest.1998.2379

DEVAPPA, R. K. et al. Activities of Jatropha curcas phorbol esters in various bioassays. Ecotoxicology and Environmental Safety, v. 78, n. 1, p. 57-62, 2012. https://doi.org/10.1016/j.ecoenv.2011.11.002

EL-GHAMERY, A. A. et al. Evaluation of cytological effects of $\mathrm{Zn}^{2+}$ in relation to germination and root growth of Nigella sativa L. and Triticum aestivum L. Mutation Research, v. 537, n. 1, p. 29-41, 2003. https://doi.org/10.1016/S1383-5718(03)00052-4

FERNANDES, T. C. C. et al. Mechanism of micronuclei formation in polyploidizated cells of Allium cepa exposed to trifuralin herbicide. Pesticide Biochemical and Physiology, v. 88, n. 3, p. 252-259, 2007. https://doi.org/10.1016/j.pestbp.2006.12.003

FISKESJÖ, G. The Allium test as a standard in environmental monitoring. Hereditas, v. 102, n. 1, p. 99-112, 1985. https://doi.org/10.1111/j.1601-5223.1985.tb00471.x

HARASHIMA, H.; SCHNITTGER, A. The integration of cell division, growth and differentiation. Current Opinion in Plant Biology, v. 13, n. 1, p. 66-74, 2010. https://doi.org/10.1016/j.pbi.2009.11.001

KING, A. J. et al. Potential of Jatropha curcas as source of renewable oil and animal feed. Journal of Experimental Botany, v. 60, n. 10, p. 2897-2905, 2009. https://doi.org/10.1093/jxb/erp025

LEME, D. M. et al. Action Mechanisms of petroleum hydrocarbons present in waters impacted by an oil spill on the genetic material of Allium cepa root cells. Aquatic Toxicology, v. 88, n. 4, p. 214-219, 2008.

https://doi.org/10.1016/j.aquatox.2008.04.012

LEME, D. M.; MARIN-MORALES, M. A. Allium cepa test in environmental monitoring: A review on its application. Mutation Research, v. 682, n. 1, p. 71-81, 2009. https://doi.org/10.1016/j.mrrev.2009.06.002

LI, C. Y. et al. Toxicity of Jatropha curcas phorbol esters in mice. Food Chemistry and Toxicology, v. 48, n. 2, p. 620-625, 2010. https://doi.org/10.1016/j.fct.2009.11.042

LIESE, A.; ROMEIS, T. Biochemical regulation of in vivo function of plant calcium-dependent protein kinases (CDPK). Biochimica et Biophysica Acta (BBA) - Molecular and Cell Biology of Lipids, v. 1833, n. 7, p. 1582-1589, 2013. https://doi.org/10.1016/j.bbamcr.2012.10.024

MAKKAR, H. P. S.; BECKER, K. Nutricional studies on rats and fish (carp Cyprinus capio) fed diets containing unheated and heated Jatropha curcas meal of a non-toxic provenance. Plant Foods for Human Nutrition, v. 53, n. 3, p.183-192, 1999. https://doi.org/10.1023/A:1008087627894

MAKKAR, H. P. S. et al. Studies on nutritive potential and toxic constituents of different provenanaces of Jatropha curcas. Journal of Agricultural and Food Chemistry, v. 45, n. 8, p. 3152-3157, 1997. https://doi.org/10.1021/jf970036j

OSUNA, L. et al. A Ca ${ }^{2+}$ dependent protein kinase with characteristics of protein kinase $\mathrm{C}$ in leaves and mesophyll cell protoplasts from Digitaria sanguinalis: possible involvement in the C4-phosphoenolpyruvate carboxylase phosphorylation cascade. Biochemical and Biophysical Research Communication, v. 314, n. 2, p. 428-433, 2004. https://doi.org/10.1016/j.bbrc.2003.12.103

R DEVELOPMENT CORE TEAM. R: A Language and Environment for Statistical Computing. R Foundation for Statistical Computing, Vienna, Austria, 2009. 
RAKSHIT, K. D. et al. S. Toxicity studies of detoxified Jatropha meal (Jatropha curcas) in rats. Food Chemestry Toxicology, v. 46, n. 12, p. 3621-3625, 2008. https://doi.org/10.1016/j.fct.2008.09.010

SMAKA-KINCL, V. et al. The evaluation of waste, surface and ground water quality using the Allium test procedure. Mutation Research, v. 368, n. 3-4, p. 171-179, 1996. https://doi.org/10.1016/s01651218(96)90059-2

SPITALER, M.; CANTRELL, D. A. Protein kinase C and beyond. Nature Immunology, v. 5, n. 1, p. 785-790, 2004. https://doi.org/10.1038/ni1097

SILVA, G. N. et al. Bioactivity of Jatropha curcas L. to insect pests of stored products. Journal of Stored Products Researches, v. 48, p. 111-113, 2012. https://doi.org/10.1016/j.jspr.2011.10.009

ZHANG, G. et al. Crystal structure of the Cys2 activator-binding domain of protein kinase Cd in complex with phorbol ester. Cell, v. 81, n. 6, p. 917-924. 1995. https://doi.org/10.1016/0092-8674(95)90011-x 